\title{
Egészségügyi dolgozók ellen elkövetett agresszív cselekmények
}

\author{
Irinyi Tamás ${ }^{1}$ - Németh Anikó Dr. ${ }^{2}$ \\ 'Szegedi Tudományegyetem, Általános Orvostudományi Kar, Szent-Györgyi Albert Klinikai Központ, \\ Pszichiátriai Klinika, Szeged \\ ${ }^{2}$ Szegedi Tudományegyetem, Egészségtudományi és Szociális Képzési Kar, \\ Egészségmagatartás és -fejlesztés Szakcsoport, Szeged
}

\begin{abstract}
Napjainkban egyre többet hallani az egészségügyi dolgozók ellen elkövetett erôszakról. Ezek olyan szándékos cselekmények, amelyeket legtöbbször a beteg vagy a hozzátartozó követ el, és a dolgozó testi, lelki sérülését okozzák rövid és hosszú távon egyaránt. Az agresszív cselekmények okai legtöbbször a páciensben keresendők, de szerepet játszanak benne az egészségügyben dolgozó szakemberek és a munkahely bizonyos jellemzői is. A szerzők a nemzetközi és hazai szakirodalomban fellelt adatokra támaszkodva ismertetik az agresszió különböző megfogalmazásait, az egészségügyi szakembereket ért agresszív cselekedetek okait. A közlemény részletesen kitér az agresszió típusaira, gyakorisági megoszlásaira, valamint ismerteti az egészségügyben dolgozó szakemberekre gyakorolt hatásokat, következményeket, illetve néhány megelőzési lehetőséget is ajánl. Orv. Hetil., 2016, 157(28), 1105-1109.
\end{abstract}

Kulcsszavak: egészségügyi dolgozók, munkahelyi agresszió, erőszak

\section{Violent acts against health care providers}

Violence against health care providers is getting more awareness nowadays. These are usually deliberate actions committed by patients or family members of them resulting in short and long term physical or psychological debilitating harm in the staff members. The causes of the violent acts are usually rooted in patient-related factors, although some characteristics of the professionals and of the workplace may also play some role. The present article presents different definitions of violence and possible reasons for violence against health care providers based on relevant international and national literature. The paper discusses the different forms and frequency of violence, furthermore, details about the effects, consequences and some options for prevention in health care settings are also included.

Keywords: healthcare workers, workplace aggression, violence

Irinyi, T., Németh, A. [Violent acts against health care providers]. Orv. Hetil., 2016, 157(28), 1105-1109.

(Beérkezett: 2016. március 22.; elfogadva: 2016. április 19.)

Az agresszió, illetve erőszak számos fogalma található meg az ezzel foglalkozó tanulmányokban. Legtöbbször az agresszió (aggression), agresszív viselkedés (aggressive behavior) fordul elő, de használják a támadás (attack), erőszak (violence) szavakat is.

Az Egészségügyi Világszervezet (WHO) megfogalmazása alapján az erőszak: „A fizikai erö vagy hatalom szándékos használata, fenyegetés vagy tényleges támadás saját maga, másik személy, csoport vagy közösség ellen, ami sérülést, halált, lelki sériulést, hibás fejlödést, nélkülözést eredményez, vagy megnöveli ezek esélyét” [1]. Egy másik megfogalmazás szerint: „A munkahelyi eröszak kategóriájába a külsó" eröszak, azaz a munkahelyhez nem tartozó személyek által gyakorolt bántalmazás, fenyegetés, fizikai vagy lélektani agresszió tartozik, amely veszélyezteti a munkavállalók egészségét, biztonságát vagy jó közérzetét” [2]. Bandura megfogalmazásában a beteg agressziója egy szándékos és céltudatos ártalmas vagy megkárosító cselekvés vagy viselkedés az ápoló irányába, ami az ápolót elkerülésre motiválja [3]. Az agresszív viselkedést a 
következőképpen írják le: „A páciens viselkedése az ápoló felé, ami az ápolónak fizikai és mentális stresszt okoz” [4]. Az eddig ismertetett fogalmakból látható, hogy az elnevezés ugyan különböző, de tartalmában mindegyik megegyezik. Egyöntetúen a munkahelyhez kötött fizikai és érzelmi sérüléseket említik, amelyeket okozhat közvetlenül a bántalmazás vagy az azzal való fenyegetés, és elkövetôként pedig olyan embereket jelölnek meg, akik nem tartoznak a munkahelyhez, tehát a betegek vagy a hozzátartozóik, eredményként pedig hosszú távú következményeket jeleznek. Hanson és mtsai tanulmányukban egészen konkrétan definiálják az egyes munkahelyi agressziótípusokat, egymástól elkülönült fogalmakat használnak. A munkahelyi agresszió fizikai agresszióra vagy erôszakkal való fenyegetésre utal (például: valakinek a sarokba szorítása, ajtó becsapása, csapkodása, fegyverrel való fenyegetés). A szóbeli agressziót (például: kiabálás, sértegetés, lekicsinylés) külön kezeli a munkahelyi agressziótól. A munkahelyi erőszakot fizikai támadásként vagy fizikailag fenyegető viselkedésként írja le (például: ököllel vagy más tárggyal való megütés, rúgás, csípés, szándékosan erôvel nekimenni valakinek). A szexuális zaklatás szexuális jellegü cselekmények előfordulása, amit támadásnak vagy megfélemlítésnek lehet tekinteni, de nem fizikai cselekvés (például: szexuális tartalmú megjegyzések, konkrét szexuális ajánlat). A szexuális agressziót szexuális természetú fizikai kontaktussal járó eseménynek nevezik (például: a személyes határok átlépése, az egyén szexuális célzattal történő megérintése) [5].

\section{Agresszió az egészségügyi dolgozók körében}

Az egészségügyben elszenvedett agressziónak több felosztása is ismeretes. Winstanley és Whittington három fó csoportot különít el. A fizikai agresszió egy fizikai erő használatával járó viselkedés, amely testi, szexuális vagy pszichés károsodást okoz az elszenvedőnek: rúgás, pofon, szúrás, rángatás, lökés, csípés, szorítás. A második csoport a szóbeli fenyegetés vagy fenyegető viselkedés, amely fizikai erő vagy hatalom használatának ígéretét jelenti, ami fizikai, szexuális, pszichés károsodástól vagy más negatív következményektốl való félelmet eredményez. A harmadik csoport a sértegetés vagy rágalom, amely megalázó, lealacsonyító, tiszteletet nélkülöző szavak használatát jelenti [6]. Gerberich és mtsai másfajta módon csoportosítják az erôszakot. Nem fizikai formája az erôszaknak a fenyegetés, szexuális zaklatás és a szóbeli bántalmazás. Fenyegetés akkor következik be, amikor valaki szavakat, gesztusokat vagy cselekedeteket használ megfélemlítő szándékkal. Szexuális zaklatásról akkor beszélünk, amikor valamilyen nem szívesen látott szexuális viselkedést (szavak vagy aktus) tapasztal valaki. Szóbeli bántalmazás, amikor egy másik személy kiabál, káromkodik, direkt más néven szólít, vagy más szavakat használ azzal a szándékkal, hogy fájdalmat okozzon. Testi táma- dásról akkor beszélünk, amikor valaki megüt, megcsap, megrúg, ellök, fojtogat, rángat, szexuálisan bántalmaz vagy más fizikai kontaktusnak tesz ki egy másik embert, amellyel szándékosan megsebesíti őt [7]. Lash és mtsai a verbális agresszió alábbi fajtáit különítik el: kiabálás, szidalmazás, megfélemlítés, zaklatás, szexuális célozgatás [8].

Az egészségügyi dolgozók ellen elkövetett agresszív cselekmények világszerte számos kutatás alapjául szolgáltak. Vannak vizsgálatok, amelyek kifejezetten az ápolókat, míg mások az egészségügyi dolgozók összességét kutatják, kevesebb származik az orvosok köréből.

Irakban vizsgált 116 ápoló $42 \%$-a élt át fizikai erôszakot egyéves periódus alatt [9], Ausztráliában 300 ápoló bevonásával készült kutatásban azt az eredményt kapták, hogy a felmérést megelőző három hónapban a válaszadó ápolók $62,8 \%$-a részesült verbális sértegetésben, $25,7 \%$-a szóbeli fenyegetésben vagy megfélemlítésben, 10,4\%-a fizikai fenyegetésben vagy megfélemlítésben, 3,1\% pedig tényleges fizikai erőszakban [10]. Az Európa több országát vizsgáló NEXT Study felmérésben a válaszadók $22,7 \%$-a szenvedett el agressziót egy hónapon belül betegektől vagy azok családtagjától, és az agresszió leggyakrabban a férfi ápolók, a fiatalabb és képzetlenebb személyzet ellen irányult [11]. Franzés mtsai által megkérdezett 123 német egészségügyi dolgozó (ápolási otthon és pszichiátriai klinika dolgozói) 70,7\%-a tapasztalt fizikai és 89,4\%-a verbális agressziót a munkahelyén. Leggyakrabban sértegetés $(92,2 \%)$, fenyegető gesztusok $(59,2 \%)$, szóbeli fenyegetés $(55,2 \%)$ és ütés $(47,4 \%)$ fordultak elő [12]. Olaszországban, 700 ápoló bevonásával készült felmérésben azt találták, hogy a válaszadók 49,4\%-a élt át legalább egyszer agresszív cselekményt a munkahelyén egyéves periódus alatt, és a többségük $(81,6 \%)$ szóbeli bántalmazásban részesült. A fizikai agresszió közül leggyakrabban $(53 \%)$ a rúgás, ütés, valamint a pofon fordult elő [13]. Gascón és mtsai által vizsgált 1826 spanyol egészségügyi dolgozó 11\%-át bántalmazták fizikálisan legalább egyszer, és 34,4\%-át fenyegették meg legalább egyszer egy év alatt [14]. Amerikában, Oregon államban, házi betegápolók körében készült felmérésben a válaszadók $51,5 \%$-a tapasztalt szóbeli agressziót, 27,6\% szexuális zaklatást, összességében a válaszadók $61,3 \%$-a tapasztalt egy év alatt valamilyen agresszív eseményt munkája során [5]. Egy kínai felmérésben 1404 közösségi ápolóból egy év alatt 51,6\%-uk tapasztalt munkahelyi erószakot, ezen belül érzelmi bántalmazást $46,23 \%$, fenyegetést $23,08 \%$, szóbeli szexuális zaklatást $10,54 \%$, fizikai támadást $9,69 \%$, szexuális támadást $4,34 \%$ szenvedett el [15]. Brazíliában 2943, alapellátásban dolgozó szakemberből 44,9\% szenvedett el munkája során sértegetést, $24,8 \%$ fenyegetést, $2,3 \%$ fizikai agressziót, és $29,5 \%$ volt tanúja erőszaknak a munkahelyen [16]. 441 spanyol egészségügyi dolgozó közül $87,2 \%$ részesült sértegetésben és fenyegetésben, $83,6 \%$ fenyegető viselkedésben, $42 \%$ rángatásban [17]. Indiában 249 egészségügyi dolgozóból 39\% élte át mun- 
kahelyén az agresszió valamilyen formáját a vizsgálatot megelőző négy hétben [18]. Nemcsak egészségügyi szakdolgozók, hanem orvosok is gyakran áldozatul esnek a betegek vagy hozzátartozók agresszív viselkedésének. Nagy-Britanniában a pszichiátrián dolgozó orvosok 60\%-a találkozik agresszióval a mindennapi munkája során [19]. Észak-Amerikában, Michiganben készült kutatás eredménye 74,9\%-os előfordulását jelezte a szóbeli fenyegetésnek és 11,7\%-os előfordulását a fizikai agreszsziónak [20]. A Lengyelországban vizsgált 501 orvos közül $85,5 \%$ találkozott munkája során megemelkedett hangnemmel, 61,5\% kapott fenyegetést, 11\% szenvedett el fizikai bántalmazást [21]. Egy marokkói felmérésben részt vevố orvosok 70\%-a élt át munkája során erőszakot, 47\% szóbeli bántalmazást, 30\% szóbeli fenyegetést és $8,3 \%$ fizikai támadást [22]. Izraelben a vizsgált orvosok $62,2 \%$-a élt át munkahelyén egy év alatt szóbeli erőszakot, $23,2 \%$ pedig fizikait [23].

Kevés hazai adat van arról, hogy a magyar egészségügyben évente mennyi erőszakos cselekményt élnek át a dolgozók. Az esetek egy részét nem is jelentik sem feletteseiknek, sem a hatóságoknak. A rendőrség bünügyi statisztikai rendszere szerint 2015-ben 139 esetben volt a sértett felsőfokú képesítéssel rendelkező ápoló, 639 esetben szakápoló, 180 esetben orvos, 117 esetben általános egészségügyi asszisztens [24]. Az egyetlen fellelhető kutatás Ivánka és mtsai által készült 2012-ben egészségügyi szakdolgozók körében. A megkérdezettek 86,1\%-a élt át szóbeli vagy fizikális agresszív cselekményt, amióta az egészségügyben dolgozik. Enyhe fizikai bántalmazást (ruha megragadása vagy rángatás) 19,9\% szenvedett el, enyhe sérülést vagy funkcionális károsodást $21 \%[25]$.

\section{Erőszakos cselekmények okai}

Az agresszióhoz számtalan ok vezethet a beteg és a személyzet részéről. A beteg részéról leggyakoribb ok az alkohol vagy kábítószer okozta befolyásoltság, amely egyébként is csökkenti a toleranciát különböző stresszhelyzetekben [26]. Különböző mentális betegségek, mint a szkizofrénia, major depresszió, bipoláris személyiségzavar két-háromszorosára növelik az agresszió rizikóját [27]. Sürgősségi osztályon gyakori ok az agresszióra, ha a betegnek sokat kell várnia [28], illetve a szúk hely és a túlzsúfoltság is ok lehet, mivel a folyosók tele vannak emberekkel, nagy a hőség és a zaj, amely növeli a feszültséget a páciensben [29]. Idősotthonok ápolóit vizsgáló összegző tanulmányban megállapították, hogy leggyakrabban akkor következik be agresszív viselkedés az ápolószemélyzettel szemben, amikor azok átlépik pácienseik személyes terét. Ilyen alkalmak a fürdetés, szájápolás, öltöztetés, ürítési szükségletek kielégítése, etetés vagy éppen a betegmozgatás. A lakók pszichoszociális stressze is kiválthat agresszív viselkedést. Ilyen stresszkeltő esemény a házastárs halála vagy a lakó kívánságának megtagadása [30]. A betegek részéról agressziót kiváltó ok le- het továbbá a szolgáltatással való elégedetlenség, rossz hír és a késedelmes ellátás [13].

A munkahelyi túlterhelés, az időnyomás oka lehet annak, hogy egy ápoló, egészségügyi dolgozó agresszív cselekmény áldozata legyen [11]. A szociális támogatás hiánya vagy alacsony szintje a felettes és a munkatársak részéről szintén kedvez az erőszakos cselekmények átélésének. A munkahelyi igénybevétel magas szintje is jelentôs okként szerepel, mivel nyomás alatt gyakrabban követnek el hibákat az ápolók, és ez kedvez az agressziónak [31]. Egy Ausztráliában végzett felmérés a kevésbé stabil munkahelyi környezetet találta erőszakot generáló oknak. Ennek a csökkent stabilitásnak az okaiként a kevés szakképzett ápolót, a megnövekedett munkamennyiséget, a beteg igényeiben bekövetkező váratlan változásokat, csökkent ápolói autonómiát, rossz kapcsolatot az orvosokkal, illetve a sok elhelyezésre váró beteget jelölték meg [32]. Amerikai otthon ápolásban dolgozó ápolók esetében a munkahelyi erőszak vagy szexuális zaklatás valamilyen formájának megtapasztalása gyakrabban fordul elő azoknál az ápolóknál, akik magasabb fokú munkahelyi stresszről, depresszióról, alvási problémákról, kiégésről számolnak be [5]. Vizsgálatok kimutatták, hogy a férfiak gyakrabban lesznek munkahelyi erôszak áldozatai, mint a nők $[11,33]$, illetve a 40 évesnél fiatalabb egészségügyi dolgozók gyakrabban lesznek agreszszív cselekmények áldozatai, mint az idősebbek. Ugyancsak nő azoknál az agresszió elszenvedésének a kockázata, akik nem részesültek agresszióval kapcsolatos felkészítő programban, illetve kényszerintézkedést hajtanak végre [34].

\section{Erőszakos cselekmények következményei}

Az egészségügyi dolgozók ellen elkövetett erőszaknak számtalan következménye lehet a dolgozóra nézve. Az incidens után gyakran dühöt, haragot, csalódást, tehetetlenséget és szorongást éreznek. A fizikai bántalmazás után kialakulhat fájdalom, és szükség lehet orvosi kezelésre is [12]. A fizikai sérülésen kívül stressz, félelem, fóbiák, alvászavar, csökkent önbecsülés is kialakulhat [2]. A bántalmazás után olyan negatív érzések jelentkeznek, mint félelem, harag és csalódottság, kétségbeesés, tehetetlenség és reménytelenség, közöny, neheztelés, illetve olyan megküzdési mechanizmusok alakulnak ki, mint a szerhasználat (alkohol, kábítószer), hiányzás a munkából, erőszak elkövetése, neheztelés és a „nem tudok ápolni” attitűd [35]. A beteg agressziójának közvetlen hatása lehet az ápolóra, amely obszervációt igénylő fizikai károsodásokat foglal magába a zúzódáson, karmoláson, vágáson át a halálig. További hatásai lehetnek a krónikus fájdalom, rémálmok, tehetetlenség, boldogtalanság, harag, érzelmi kimerülés és deperszonalizáció, elszigetelődés, a munkával való elégedetlenség és a pályaelhagyás [36]. Olyan hosszú távú pszichés következményei is lehetnek, mint a poszttraumás stressz betegség és a kiégés [11], valamint idegesség érzése, önértékelés csökkenése, 
visszatérő gondolatok arról, hogy mit kellett volna jobban csinálni [37]. A munkahelyre nézve is lehet negatív következménye annak, ha egy dolgozót erőszak ér. Gyakoribbá válnak a hiányzások, romlik a munkatársakkal való kapcsolat [2], a munkateljesítmény [15], a munkával való elégedettség, csökken a munkahely iránti elkötelezettség szintje [31]. Az érzelmi erőszak következménye lehet, hogy a dolgozó felmond, elhagyja munkahelyét [32].

\section{Az agresszió megelözésének lehetőségei}

A fentebb ismertetett nemzetközi tanulmányok sora bizonyítja, hogy az egészségügyi dolgozók nagy hányadát érinti a munkahelyi erőszak, agresszió, amelynek elkövetői leggyakrabban a betegek vagy hozzátartozóik. E cselekményeknek számtalan testi és lelki következménye lehet, hosszú távú kihatásai az áldozatra és a munkahelyre is, ezért szülkséges nagy hangsúlyt fektetni a prevencióra. Vizsgálat támasztotta alá a kommunikációs jártasság fejlesztésére szolgáló program hatékonyságát. Ennek a programnak a lényege, többek között, hogy a résztvevőknek DVD-n vetítenek jó és rossz kommunikációt szemléltető példákat, amelyeket közben elemeznek. Pozitív hatásként meg kell említeni, hogy csökken az agresszív események száma, az érzelmi distressz, valamint fokozódik a mentális jóllét [38]. Szükséges olyan tréningek szervezése is a dolgozók számára, ahol megtanulják, hogy melyek azok a jelek, amelyek az agresszív viselkedés bekövetkeztére utalnak, így megelőzhető a sérelem. Szükséges továbbá együttmúködni a hatóságokkal a megelőzésben (rendőrség, biztonsági szolgálat) [39]. A megelőzésben fontos szerepet játszik a dolgozók közötti jó kommunikáció kifejlesztése. Erre mód lehet a csapatépítő tréningeken való részvétel, amelynek hatására a munkakörnyezet javul, így megelőzhetőek a munkaközösségen belüli konfliktusok, ezáltal pozitív hatása lehet a betegek/hozzátartozók által elkövetett erőszak kivédésére is [40]. Magyarországon az egészségügyi szakdolgozók számára több alkalommal is szerveztek olyan továbbképzést, amely az agresszió lehetséges megelőzésére szolgáló elméleti és gyakorlati ismereteket adott át [41].

Anyagi támogatás: A közlemény megírása anyagi támogatásban nem részesült.

Szerzői munkamegosztás: I. T.: Problémafelvetés, magyar nyelvű forrásmúvek felkutatása, publikáció megírása. N. A.: Idegen nyelvü forrásmúvek felkutatása, fordítása. A cikk végleges változatát a szerzők elolvasták és jóváhagyták.

Érdekeltségek: A szerzőknek nincsenek érdekeltségeik.

\section{Irodalom}

[1] Krug, E. G., Dablberg, L. L., Mercy, J. A., et al.: World report on violence and health. World Health Organization, Geneva, 2002. http://www.who.int/violence_injury_prevention/violence/ world_report/en/summary_en.pdf

[2] Pál, A.: Correlations of work-related stress and intimidation and violence at the workplace. [A munkával összefüggő stressz, valamint a munkahelyi megfélemlítés és erôszak összefüggései.] Foglalkozás-Egészségügy, 2004, 9(5), 1-15. [Hungarian]

[3] Bandura, A.: Self-efficacy: The exercise of control. W H Freeman/Times Books/ Henry Holt \& Co, New York, NY, US, 1997.

[4] Sato, K., Wakabayashi, T., Kiyoshi-Teo, H., et al.: Factors associated with nurses' reporting of patients' aggressive behavior: A cross-sectional survey. Int. J. Nurs. Stud., 2013, 50(10), $1368-1376$.

[5] Hanson, G. C., Perrin, N. A., Moss, H., et al.: Workplace violence against homecare workers and its relationship with workers health outcomes: a cross-sectional study. BMC Public Health, $2015,15,11$

[6] Winstanley, S., Whittington, R.: Aggression towards health care staff in a UK general hospital: variation among professions and departments. J. Clin. Nurs., 2004, 13(1), 3-10.

[7] Gerberich, S. G., Church, T. R., McGovern, P. M., et al.: An epidemiological study of the magnitude and consequences of work related violence: the Minnesota Nurses' Study. Occup. Environ. Med., 2004, 61(6), 495-503.

[8] Lash, A. A., Kulakaç, O., Buldukoglu, K., et al.: Verbal abuse of nursing and midwifery students in clinical settings in Turkey. J. Nurs. Educ., 2006, 45(10), 396-403.

[9] AbuAlRub, R. F., Khalifa, M. F., Habbib, M. B.: Workplace violence among Iraqi hospital nurses. J. Nurs. Scholarsh., 2007, $39(3), 281-288$.

[10] Hills, D.: Relationships between aggression management train ing, perceived self-efficacy and rural general hospital nurses' experiences of patient aggression. Contemp. Nurse, 2008, 31(1), 20-31.

[11] Camerino, D., Estryn-Behar, M., Conway, M. P., et al.: Work-related factors and violence among nursing staff in the European NEXT study: A longitudinal cohort study. Int. J. Nurs. Stud., 2008, 45(1), 35-50

[12] Franz, S., Zeh, A., Schablon, A., et al.: Aggression and violence against health care workers in Germany - a cross sectional retrospective survey. BMC Health Serv. Res., 2010, 10, 51.

[13] Zampieron, A., Galeazzo, M., Turra, S., et al.: Perceived aggression towards nurses: study in two Italian health institutions. J. Clin. Nurs., 2010, 19(15-16), 2329-2341.

[14] Gascón, S., Leiter, M. P., Andrés, E., et al.: The role of aggressions suffered by healthcare workers as predictors of burnout. J. Clin. Nurs., 2013, 22(21-22), 3120-3129.

[15] Lin, W. Q., Wu, J., Yuan, L. X., et al.: Workplace violence and job performance among community healthcare workers in China: The mediator role of quality of life. Int. J. Environ. Res. Public Health, 2015, 12(11), 14872-14886.

[16] Da Silva, A. T., Peres, M. F., de Souza Lopes, C., et al.: Violence at work and depressive symptoms in primary health care teams: a cross-sectional study in Brazil. Soc. Psychiatry Psychiatr. Epidemiol., 2015, 50(9), 1347-1355.

[17] Bernaldo-De-Quirós, M., Piccini, A. T., Gómez, M. M., et al.: Psychological consequences of aggression in pre-hospital emergency care: Cross sectional survey. Int. J. Nurs. Stud., 2015, 52(1), 260-270.

[18] Raveesh, B. N., Lepping, P., Lanka, S. V., et al.: Patient and visitor violence towards staff on medical and psychiatric wards in India. Asian J. Psychiatry, 2015, 13, 52-55. 
[19] Shaw, M. M.: Aggression toward staff by nursing home residents: findings from a grounded theory study. J. Gerontol. Nurs., 2004, 30(10), 43-54.

[20] Kowalenko, T., Walters, B. L., Khare, R. K., et al.: Workplace violence: a survey of emergency physicians in the state of Michigan. Ann. Emerg. Med., 2005, 46(2), 142-147.

[21] Jankowiak, B., Kowalczuk, K., Krajewska-Kulak, E., et al.: Exposure the doctors to aggression in the workplace. Adv. Med. Sci. 2007, 52(Suppl. 1), 89-92.

[22] Belayachi, J., Berrechid, K., Amlaiky, F., et al.: Violence toward physicians in emergency departments of Morocco: prevalence, predictive factors, and psychological impact. J. Occup. Med. Toxicol., 2010, 5, 527

[23] Kitaneh, M., Hamdan, M.: Workplace violence against physicians and nurses in Palestinian public hospitals: a cross-sectional study. BMC Health Serv. Res., 2012, 12, 469.

[24] System of criminal justice statistics. [Bűnügyi statisztikai rendszer.] 2015. https://bsr.bm.hu/SitePages/ExcelMegtekinto.as px? ExcelName $=$ https $\% 3 \mathrm{a} \% 2 \mathrm{f} \% 2 \mathrm{fbsr} . \mathrm{bm}$. hu $\% 2 \mathrm{fSertettiAdatok}$ \%2fS\%C3\% A9rtettek+sz\%C3\%Alma+az+elk\%C3\%B6vet\%C3\%A 9s+helye+ szerint.xlsx [Hungarian]

[25] Ivánka, T., Irinyi, T., Rudisch, T.: Occurrences involving aggression among healthcare workers. [Agresszív cselekmények előfordulásának vizsgálata egészségügyi szakdolgozók körében.] Nővér, 2014, 27(2), 19-25. [Hungarian]

[26] Farrell, G. A., Shafiei, T.: Workplace aggression, including bullying in nursing and midwifery: a descriptive survey (the SWAB study). Int. J. Nurs. Stud., 2012, 49(11), 1423-1431.

[27] Friedman, R. A.: Violence and mental illness - how strong is the link? N. Engl. J. Med., 2006, 355(20), 2064-2066.

[28] Crilly, J., Chaboyer, W., Creedy, D.: Violence towards ED nurses by patients. Accid. Emerg. Nurs., 2004, 12(2), 67-73.

[29] Angland, S., Dowling, M., Casey, D.: Nurses' perceptions of the factors which cause violence and aggression in the emergency department: a qualitative study. Int. Emerg. Nurs., 2014, 22(3), 134-139.

[30] Zeller, A., Hahn, S., Needham, I., et al.: Aggressive behavior of nursing home residents toward caregivers: a systematic literature review. Geriatr. Nurs., 2009, 30(3), 174-187.
[31] Demir, D., Rodwell, J.: Psychosocial antecedents and conse quences of workplace aggression for hospital nurses. J. Nurs. Scholarsh., 2012, 44(4), 376-384.

[32] Roche, M., Diers, D., Duffield, C., et al.: Violence toward nurses, the work environment, and patient outcomes. J. Nurs. Scholarsh., 2010, 42(1), 13-22.

[33] Miedema, B., Easley, J., Fortin, P., et al.: Disrespect, harassment, and abuse: All in a day's work for family physicians. Can. Fam. Physician, 2009, 55(3), 279-285.

[34] Ayranci, U., Yenilmez, C., Balci, ., et al.: Identification of violence in Turkish health care settings. J. Interpers. Violence, 2006, 21(2), 276-296.

[35] Bimenyimana, E., Poggenpoel, M., Myburgh, C., et al.: The lived experience by psychiatric nurses of aggression and violence from patients in a Gauteng psychiatric institution. Curationis, 2009, $32(3), 4-13$

[36] Winstanley, S., Whittington, R.: Anxiety, burnout and coping styles in general hospital staff exposed to workplace aggression: a cyclical model of burnout and vulnerability to aggression. Work Stress, 2002, 16(4), 302-315.

[37] Tan, M. F., Lopez, V., Cleary, M.: Nursing management of aggression in a Singapore emergency department: A qualitative study. Nurs. Health Sci., 2015, 17(3), 307-312.

[38] Swain, N., Gale, C.: A communication skills intervention for community healthcare workers reduces perceived patient aggression: a pretest-posttest study. Int. J. Nurs. Stud., 2014, 51(9), 1241-1245.

[39] Deák, G.: Hospital security-preventing and managing workplace violence in health care sector. AARMS, 2011, 10(1), 161-171.

[40] Colling, R. L.: Hospital and healthcare security. Fourthy edition. Butterworth-Heinemann, Boston, 2001.

[41] Ivánka, T., Irinyi, T., Rudisch, T., et al.: Aggression management programme for healthcare workers. [Agresszió megelőzését célzó továbbképzés egészségügyi szakdolgozók körében.] Nővér, 2014, 27(4), 11-17. [Hungarian]

(Irinyi Tamás,

Szeged, Kálvária sgt. 57., 6725 e-mail: irinyikutatas@gmail.com)

\title{
A rendezvények és kongresszusok híranyagának leadása
}

a lap megjelenése előtt legalább 40 nappal lehetséges, a 6 hetes nyomdai átfutás miatt. Kérjük megrendelőink szíves megértését.

\author{
A híranyagokat a következő címre kérjük: \\ Orvosi Hetilap titkársága: Budai.Edit@akkrt.hu \\ Akadémiai Kiadó Zrt.
}

